\title{
Continued Multicolumns Bioleaching for Low Grade Uranium Ore at a Certain Uranium Deposit
}

\author{
Gongxin Chen, Zhanxue Sun, and Yajie Liu \\ State Key Laboratory Breeding Base of Nuclear Resources and Environment, East China University of Technology, \\ Nanchang, Jiangxi 330013, China \\ Correspondence should be addressed to Gongxin Chen; cgx95121@163.com
}

Received 26 April 2016; Revised 19 June 2016; Accepted 22 June 2016

Academic Editor: Tianyi Kou

Copyright (C) 2016 Gongxin Chen et al. This is an open access article distributed under the Creative Commons Attribution License, which permits unrestricted use, distribution, and reproduction in any medium, provided the original work is properly cited.

Bioleaching has lots of advantages compared with traditional heap leaching. In industry, bioleaching of uranium is still facing many problems such as site space, high cost of production, and limited industrial facilities. In this paper, a continued column bioleaching system has been established for leaching a certain uranium ore which contains high fluoride. The analysis of chemical composition of ore shows that the grade of uranium is $0.208 \%$, which is lower than that of other deposits. However, the fluoride content (1.8\% of weight) is greater than that of other deposits. This can be toxic for bacteria growth in bioleaching progress. In our continued multicolumns bioleaching experiment, the uranium recovery $(89.5 \%)$ of 4 th column is greater than those of other columns in 120 days, as well as the acid consumption $(33.6 \mathrm{~g} / \mathrm{kg})$. These results indicate that continued multicolumns bioleaching technology is suitable for leaching this type of ore. The uranium concentration of PLS can be effectively improved, where uranium recovery can be enhanced by the iron exchange system. Furthermore, this continued multicolumns bioleaching system can effectively utilize the remaining acid of PLS, which can reduce the sulfuric acid consumption. The cost of production of uranium can be reduced and this benefits the environment too.

\section{Introduction}

Biological metallurgy technology does not have a long history in leaching minerals. Bioleaching is one of the most active technologies [1]. For introduction of bacterial leaching process at uranium leaching can enhance the kinetics of leaching and strengthen its process, bioleaching has been paid great attention in uranium industry in recent years. By this technology, the leaching time can be shortened and the recovery of minerals can be improved and the production costs can be reduced. This technology has been used in the production [2,3] or is still in the laboratory research stage [4]. Leaching in columns simulates percolation leaching because the conditions are very similar to those in the heap [5].

In China, bioleaching has been greatly improved in uranium industry. However, we still face some keys which greatly impact this technology's application, such as the bacteria adapting to the leaching environment, the tolerance of toxic elements in leaching solution, not well understanding the mechanism and the biochemical kinetics, and the leaching process needing to be optimized [6]. In China, hard-rock-type uranium (such as granite-type) deposits are using heap leaching widely in industry. In this paper, one of the biggest granite uranium deposits located in south China with high fluoride mineral is selected for study. In this deposit's industrial producing practice, acid is often used as irrigating solution. However, the uranium concentration of pregnant leaching solution (PLS) is low. This affects the adsorption efficiency. Another problem is that the acid consumption (about $55 \mathrm{~g} / \mathrm{kg}$ ) is still too high and the recovery is low which lead to the high product cost. The company who owns this deposit needs a new technology to solve this problem. So we try to use continued multicolumns bioleaching in uranium to model multiheaps bioleaching as to improve the production efficiency and reduce the production cost.

\section{Materials and Methods}

2.1. Materials. A solid sample of uranium ore from the normal production of ore in this deposit plant was used. This type of uranium ore is mainly distributed in Taoshan 

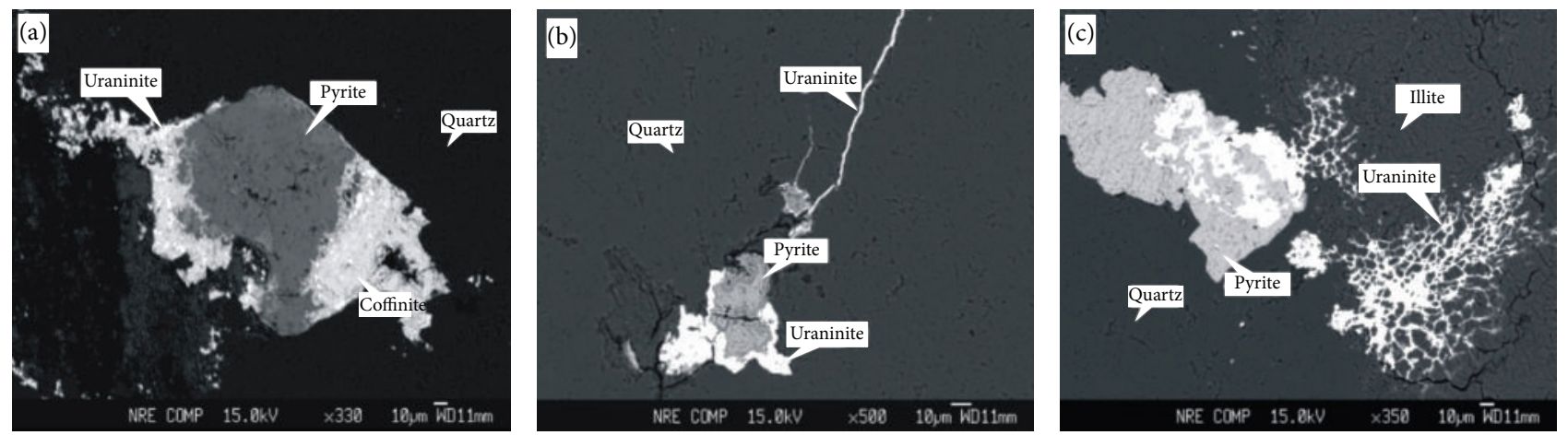

FIGURE 1: Back-scattered electron image by EPMA before leaching. ((a), (b), and (c)) Uranium minerals accompanied by pyrite. (b) Uranium minerals are located in the tiny fractures of quartz. (c) Uranium minerals are located in the tiny fractures of illite. ((a) and (b)) Images from Zhihua Wang and Baoqin Hu (2013) and (c) Xinbo Zhao (2014).

TABLE 1: Chemical and mineralogical composition of the ore sample used in column bioleaching.

\begin{tabular}{lcc}
\hline Composition & Weight\% & $\begin{array}{c}\text { Mineralogical } \\
\text { composition }\end{array}$ \\
\hline $\mathrm{SiO}_{2}$ & 78.46 & \\
$\mathrm{Al}_{2} \mathrm{O}_{3}$ & 7.14 & \\
$\mathrm{Fe}_{2} \mathrm{O}_{3}$ & 1.34 & \\
$\mathrm{~K}_{2} \mathrm{O}$ & 2.71 & \\
$\mathrm{Na}{ }_{2} \mathrm{O}$ & 0.25 & Quartz \\
$\mathrm{FeO}$ & 0.7 & Potash feldspar \\
$\mathrm{MgO}$ & 0.5 & Calcite \\
$\mathrm{P}_{2} \mathrm{O}_{5}$ & 0.021 & \\
$\mathrm{TiO}_{2}$ & 0.03 & \\
$\mathrm{CaO}$ & 4.2 & \\
$\mathrm{U}$ & 0.208 & \\
$\mathrm{BaO}_{\mathrm{S}}$ & 0.01 & \\
$\mathrm{~S}$ & 0.16 & \\
$\mathrm{~F}$ & 1.8 & \\
$\mathrm{CO}_{2}$ & 1.2 & \\
$\mathrm{~S}^{-1-2}$ & 0.1 & \\
\hline
\end{tabular}

Zhuguangshan mineralization belt. It has a relationship with the granite of Yanshan period in space and genesis. Uranium mineralizations are product in low level structure of tectonic fault, which mainly contain pitchblende, coffinite, fluorite silicate uranium, lead, and zinc.

Table 1 shows the chemical and mineralogical composition of the sample. Elemental analysis of the sample by a wet chemical method involving hydrofluoric acid digestion and measurement by atomic absorption spectrophotometry (AAS; Perkin Elmer, Model 3100) indicated that the major constituent of the sample was $\mathrm{SiO}_{2}$, weight of more than $78 \%$, and the second is $\mathrm{Al}_{2} \mathrm{O}_{3}$, weight of $7 \%$, and a small amount of $\mathrm{FeO}, \mathrm{S}, \mathrm{Na}_{2} \mathrm{O}, \mathrm{P}_{2} \mathrm{O}_{5}, \mathrm{MgO}, \mathrm{TiO}_{2}, \mathrm{BaO}$, and so forth. Fluoride element analysis of the sample by potassium hydroxide digestion and measurement by fluoride electrode indicated that fluoride weight is high (1.8\%). This indicates these ores contain lots of fluoride mineral. It can have certain influence on the growth of microorganisms. The sulfur weight is $0.16 \%$ and the uranium weight is $0.208 \%$. This uranium ore belongs to a low grade type. The sample was also analyzed by X-ray diffraction (XRD) using a Panalytical X'Pert PRO MPD with $\mathrm{CuK} \alpha$ radiation $(40 \mathrm{kV}, 50 \mathrm{~mA})$, equipped with automatic divergence slit, sample spinner, and a graphite secondary monochromatic and proportional detector [7]. XRD analysis indicated that silica $\left(\mathrm{SiO}_{2}\right)$, potash feldspar $\left(\mathrm{K}\left(\mathrm{AlSi}_{3} \mathrm{O}_{8}\right)\right)$, fluorite $\left(\mathrm{CaF}_{2}\right)$, and calcite $\left(\mathrm{CaCO}_{3}\right)$ were the dominant phases present.

Back-scattered electron image shows that the uranium minerals are located in the tiny fractures of the ore and they are accompanied by pyrite as shown in Figure 1. This indicates that once pyrite is leached; the surface area of those uraninite and coffinite minerals will be greatly increased. Those tiny fractures around uranium minerals will be enlarged as well. Furthermore, when the pyrite is dissolved or, more precisely, is oxidized, ferric iron is produced which can offer good oxidizing for those reduced-type uranium minerals. Iron oxidizing bacteria are a good worker who can do this job.

In our study, a strain of mesospheric iron oxidizing bacteria (Acidithiobacillus ferrooxidans mixed with Leptospirillum ferriphilum, named B3mYP1Q) provided by our university was used throughout the investigations. It was domesticated by PLS with high fluorine concentration (3 to $4 \mathrm{~g} / \mathrm{L}$ of total F). Acidithiobacillus ferrooxidans is Gram-negative bacteria [8], characterized by nonsporulating rods, $0.5-0.6 \mu \mathrm{m}$ wide and 1.0-2.0 $\mu \mathrm{m}$ long with rounded ends, and occurring singly or in pairs or rarely in short chains. The bacteria are also known to be motile by means of a single polar flagellum. All of these characteristics were observed during the isolation of the strain used. The compositions of the nutrient growth medium are from PLS at this deposit.

2.2. Experimental Bioleaching. Leaching system consists of serial organic glass columns with a diameter of $150 \mathrm{~mm}$ and a height of $2 \mathrm{~m}$. In the bottom of each column gravel and pebbles were cushioned at $10 \mathrm{~cm}$ height. The ratio of the internal diameter of the column to the height of ore is important for the leaching solution percolates more efficiently. It has been established that this ratio must be greater than 4 and not in excess of 20 in order to avoid any effects of the wall $[9,10]$. As a consequence, a ratio of 10 was adopted in 


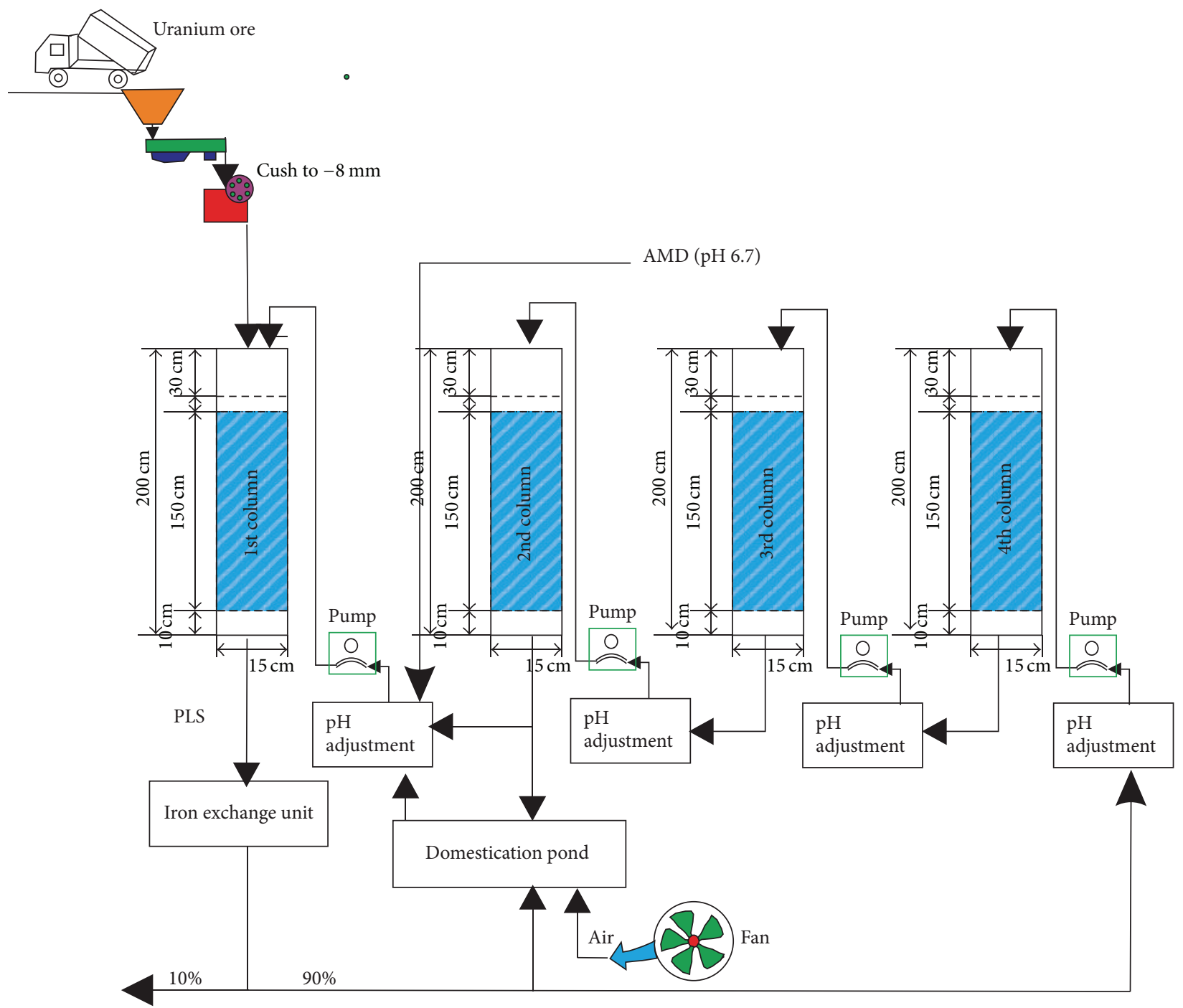

Neutralization

FIGURE 2: Schematic of continued multicolumn bioleaching system.

these experiments. In each column, the ore is built up $150 \mathrm{~cm}$ high and on top there are loading cobble and gravel $10 \mathrm{~cm}$ high. Plastic film was covered on the top of both leaching column and liquid collecting tank to reduce evaporation. The irrigation is powered by a peristaltic pump. The speed of pump is changed in the test to control the time and intensity. Test process is $120 \mathrm{~d}$ for the uranium leaching cycle, consisting of four columns as shown in Figure 2. The test process and the specific implementation process are as follows: 4 columns are, respectively, set, first column (acid leaching stage and domestication stage), second column (bioleaching stage), third column (bioleaching stage), and the last column (final leaching stage). Each column acidification stage is $30 \mathrm{~d}$, and domestication stage is $30 \mathrm{~d}$, and bioleaching stage is 30 days and final leaching stage is 30 days. Afer $120 \mathrm{~d}$ of leaching, the last column was unloaded out of this system and a new column was added in. Before irrigation of the former column, the $\mathrm{pH}$ of PLS should be adjusted to 1.8. For comparison, a single column test is conducted at the same time. Sample volumes of liquid were extracted periodically and the $\mathrm{pH}$ and redox potential (Eh) were measured. The $\mathrm{U}_{3} \mathrm{O}_{8}, \mathrm{Fe}^{\text {Total }}$, and $\mathrm{Fe}^{2+}$ content were also analyzed.

\section{Results and Discussion}

3.1. Acid Consumption during Bioleaching. There exist consumptive acid minerals such as calcite (chemical analysis of the weight of $\mathrm{CO}_{2} 1.2 \%$, of calcite about $2.7 \%$ ) in this ore. Thus, during bioleaching, the $\mathrm{pH}$ of irrigating solution in the column will be increased. When the $\mathrm{pH}$ value of irrigating solution reaches over 2.5 , the ferric iron will be precipitated as goethite. As shown in Figure 3, the $\mathrm{pH}$ values of PLS in the first 5 leaching days decrease very fast but are still greater than 4 . In the next five days, $\mathrm{pH}$ values decrease slowly compared with the former 5 days and reach around 2.0 at the 10th day. This indicates that during this stage most easily consumptive acid minerals such as calcite of this ore are almost reacted by acid in the large fractures. However, 


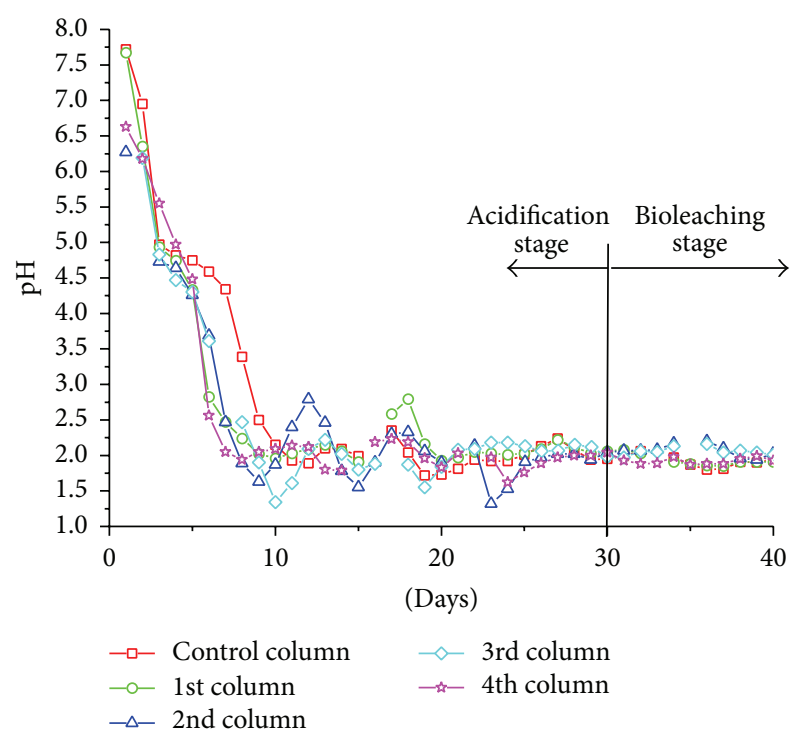

FIgUre 3: $\mathrm{pH}$ value of the PLS in the first 40 days.

some consumptive acid minerals in small fractures will be reacted more slowly. On the other hand, the mesospheric iron oxidizing bacteria of Acidithiobacillus ferrooxidans and Leptospirillum ferriphilum which are used in this experiment are more active in $\mathrm{pH}$ of 1.5 to 2 than in other $\mathrm{pH}$ values. Therefore, the $\mathrm{pH}$ of irrigating solution cannot be lower than 1.5 or higher than 2 . When $\mathrm{pH}$ is lower than 1.5 , the precipitation of some jarosite-type basic compounds will be found in the column [11]. These type of precipitations are difficult to be dissolved by strong acid and that will decrease the permeability of the column [12]. The uranium minerals will be wrapped up by them. As a consequence, they hinder the irrigating solution to react with the uranium minerals and the uranium recovery is decreased. In acidification stage, therefore, the acid concentration should be decreased as well. In our experiment, the concentration of acid of irrigating solution is reduced from $40 \mathrm{~g} / \mathrm{L}$ to $5 \mathrm{~g} / \mathrm{L}$ in 10 days for those easier reactant consumptive acid minerals in small fractures and from $5 \mathrm{~g} / \mathrm{L}$ to $3 \mathrm{~g} / \mathrm{L}$ in the next around 20 days for those slow reactants in small fractures. Under these circumstances, the precipitation of both goethite and jarosite-type basic compounds will not occur in the next bioleaching stage and the bacterium will grow in the column as bacteria are adapted to this $\mathrm{pH}$ and the culture from the irrigating solution (PLS of $\mathrm{pH}$ adjustment).

After 120 days' leaching, the total acid consumption for each column is $45.73,43.74,42.38,40.23$, and $33.6 \mathrm{~g} / \mathrm{kg}$, respectively, in this type of system as shown in Figure 4. In the first 10 days of acidification stage, acid consumption curve increases fast linearly and is up to around $30 \mathrm{~g} / \mathrm{kg}$. In the next 20 days, acid consumption increases still fast but it is lower than that in the first 10 days. And then in the next bioleaching stage, acid consumption still increase slowly because some acid needs to be added in the bacteria domestication pond for $\mathrm{pH}$ adjustment and there are still some consumptive acid minerals in tiny fracture which are not reacted by acid in

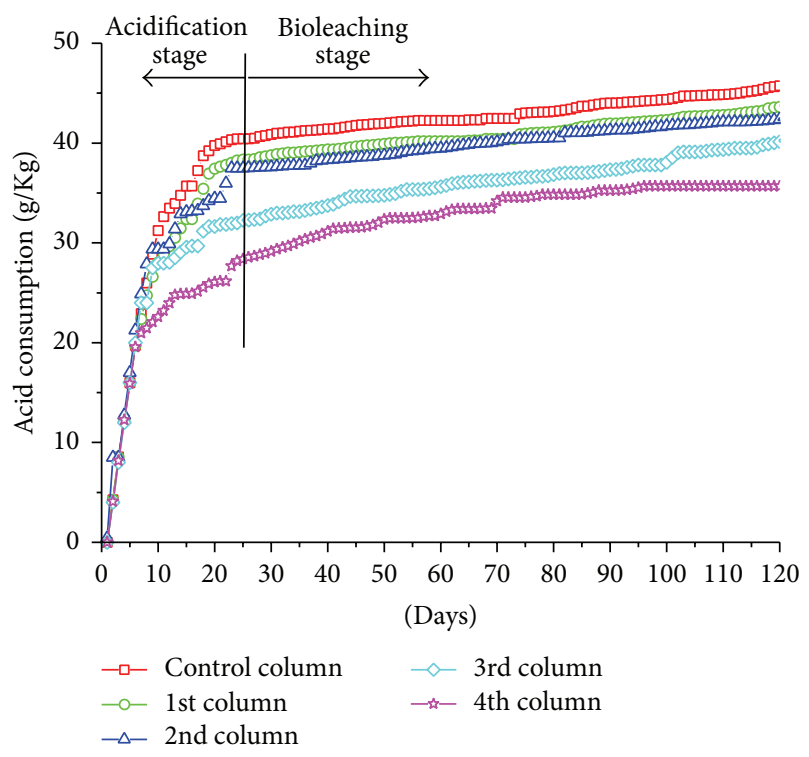

FIgURE 4: The acid consumption with the column's order.

the former stage. The total acid consumption of 1st column is highest and that of the last column is lowest. This result shows that the acid consumption is in good accordance with the column's order and this system can help to save acid consumption. Moreover, the acid consumption of the 1st column and that of the 2 nd column are very similar. Because the first column is the initial column in this type of system and the acid amount of PLS from the 1st column is small, the irrigating solution of 2 nd column needs to add more acid for $\mathrm{pH}$ adjustment using PLS from the 1st column. The acid of the 3rd and 4th column, however, can accumulate acid from the former columns. It is found that the acid consumption of the later columns will be lower than that of the former ones.

3.2. Redox Potentials (Eh) of Irrigating Solution and PLS. During this experiment, both redox potentials of irrigating solution and PLS are measured in each day. Redox potentials of from 1st column to 4 th column are presented in Figures 5(a), 5(b), 5(c), and 5(d). During the acidification process of leaching of uranium, the redox potentials of leaching solution are low and varied between $350 \mathrm{mV}$ and $400 \mathrm{mV}$ (versus SCE). In this type of ore, many minerals such as pyrite and urinate belong to reduced substances. In the leaching progress, they can be oxidized by ferric iron or $\mathrm{O}_{2}$ of the solution [13]. In the process of acidification, reducing substances in ore are leached into the PLS and decrease Eh of PLS:

$$
\begin{gathered}
2 \mathrm{FeS}_{2}+7 \mathrm{O}_{2}+2 \mathrm{H}_{2} \mathrm{O} \stackrel{\text { air }}{\longrightarrow} 2 \mathrm{FeSO}_{4}+2 \mathrm{H}_{2} \mathrm{SO}_{4} \\
\mathrm{FeS}_{2}+14 \mathrm{Fe}^{3+}+8 \mathrm{H}_{2} \mathrm{O} \longrightarrow 16 \mathrm{H}^{+}+2 \mathrm{SO}_{4}^{2-}+15 \mathrm{Fe}^{2+}
\end{gathered}
$$

As shown in Figure 5, in each column in the bioleaching process, redox potentials increased obviously compared with the former acid leaching period, and they reach $500 \mathrm{mv}$ (SCE) rapidly. After bioleaching period, redox potentials of PLS are significantly higher than the correspondence leaching solutions. This indicates that the bacteria grow well in these 


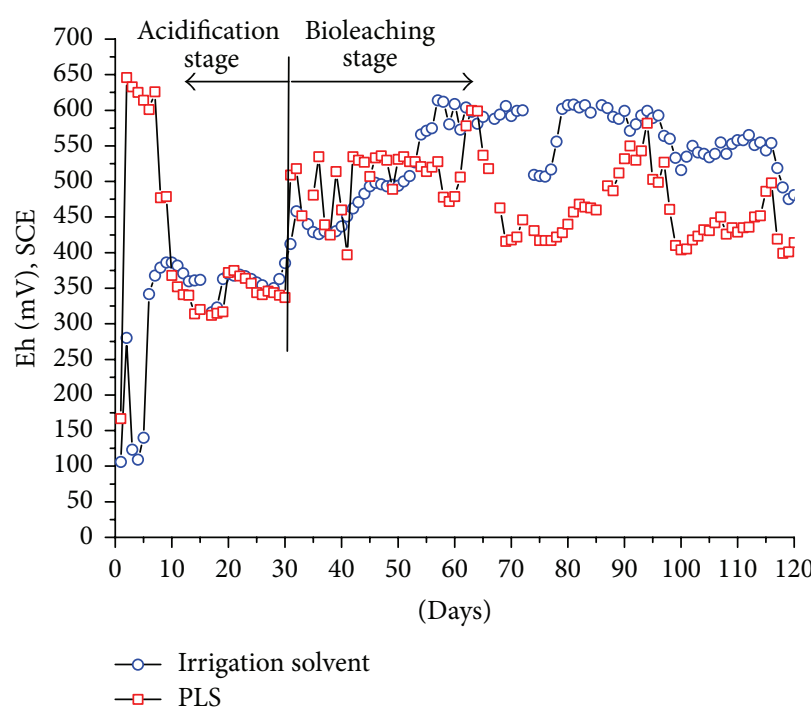

(a)

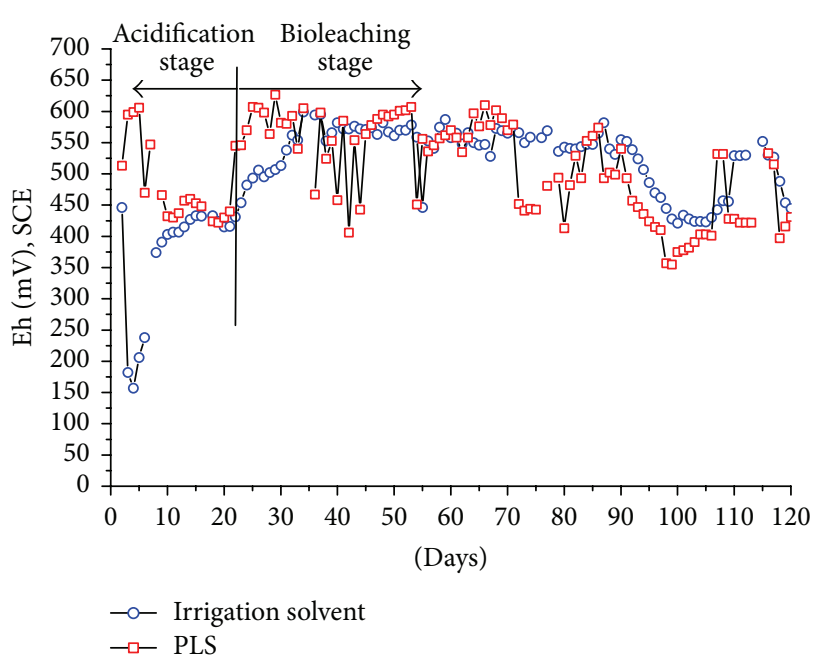

(c)

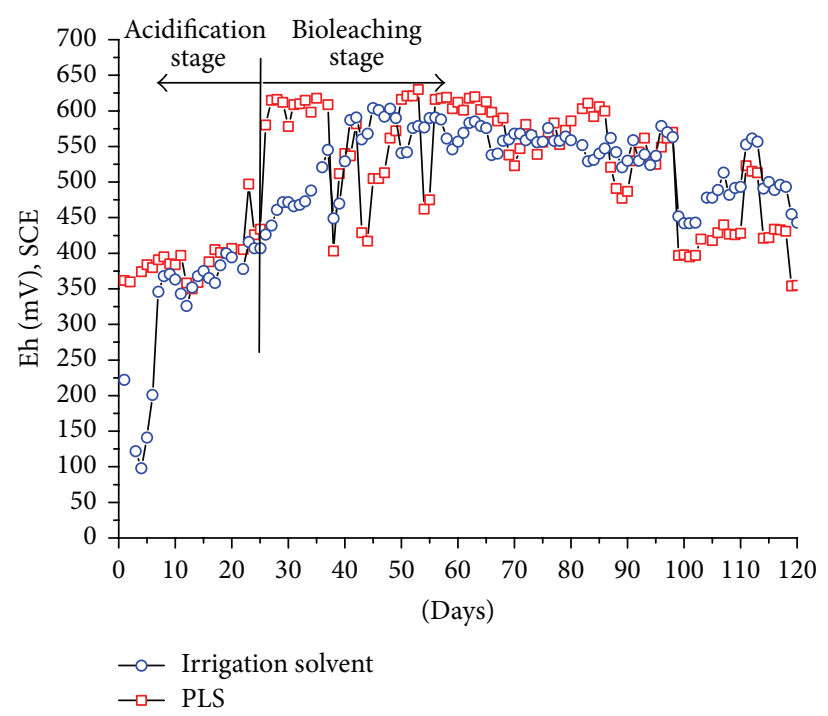

(b)

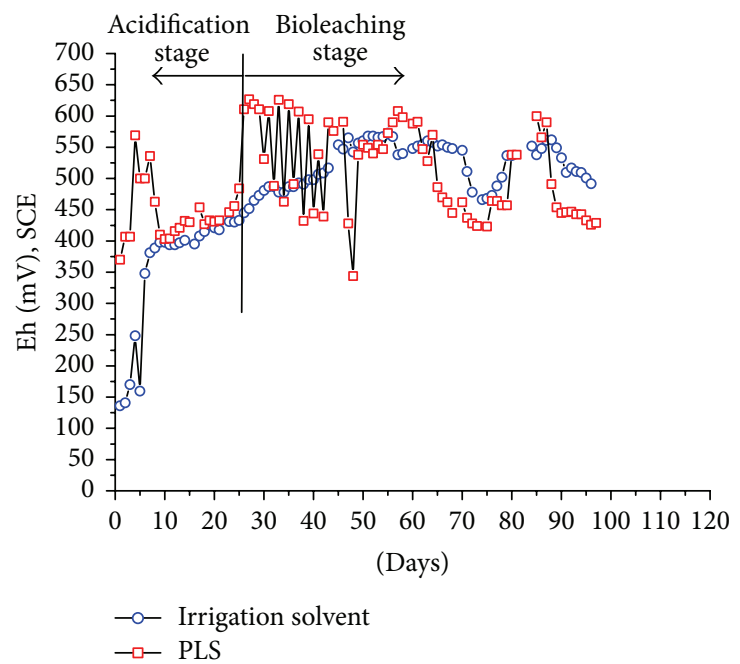

(d)

Figure 5: Relationship between each column of Eh value. (a) 1st column; (b) 2nd column; (c) 3rd column; (d) 4th column.

columns. They enhance the ferrous oxidizing and produce ferric iron to oxidize pyrite and uraninite as shown in the following equations [14]:

$$
\begin{aligned}
& 4 \mathrm{FeSO}_{4}+\mathrm{O}_{2}+2 \mathrm{H}_{2} \mathrm{SO}_{4} \stackrel{\text { At.f. L.f }}{\longrightarrow} 2 \mathrm{Fe}_{2}\left(\mathrm{SO}_{4}\right)_{3}+2 \mathrm{H}_{2} \mathrm{O} \\
& \mathrm{UO}_{2}+\mathrm{Fe}_{2}\left(\mathrm{SO}_{4}\right)_{3} \longrightarrow \mathrm{UO}_{2} \mathrm{SO}_{4}+2 \mathrm{FeSO}_{4} \\
& \mathrm{U}_{3} \mathrm{O}_{8}+\mathrm{Fe}_{2}\left(\mathrm{SO}_{4}\right)_{3}+2 \mathrm{H}_{2} \mathrm{SO}_{4} \\
& \quad \longrightarrow 3 \mathrm{UO}_{2} \mathrm{SO}_{4}+2 \mathrm{FeSO}_{4}+2 \mathrm{H}_{2} \mathrm{O}
\end{aligned}
$$

During bioleaching period, redox potentials increase and uranium concentrations are also increased as shown in Figures 5 and 6 . With the variation of Eh of irrigating solution, the uranium concentration is varied too. Therefore, high Eh value is good benefit for oxidizing fourth valence uranium [15]. Normally, the bacteria need $24 \mathrm{hr}$ of cultivation.
In this type of system, one purpose is the increasing redox potentials of this system; the other purpose is that the iron oxidizing bacteria can grow in the column. The irrigation frequency is $12 \mathrm{hr} /$ day. Irrigation method is that one day we use bacteria as irrigation solution after domestication by air in 24 hours for increasing the activity of bacteria and also increasing the redox potential, and the next day we use PLS from the former column which contains ferrous iron as the nutrition for those iron oxidizing bacteria in order to help the bacteria grow in the ore. The redox potential of PLS is much lower than that of bacteria culture. For the bacteria culture and the PLS as irrigation solution changed in turns, the red curves of irrigation solution are more fluctuant than blue curve of PLS.

3.3. Uranium Leaching. In the acidification period, there occurs a uranium concentration peak. Most of sixth valence 


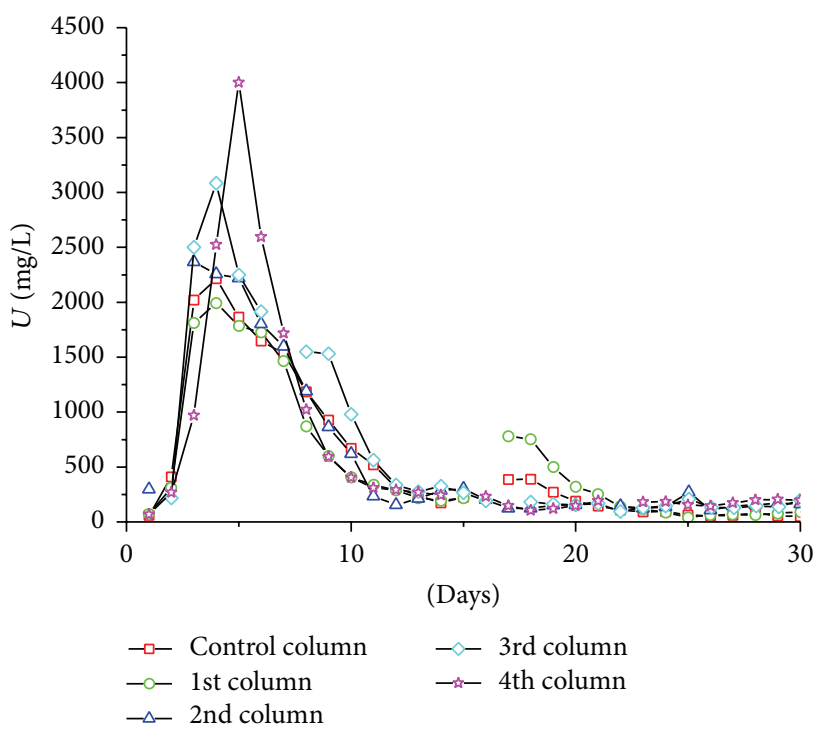

(a)

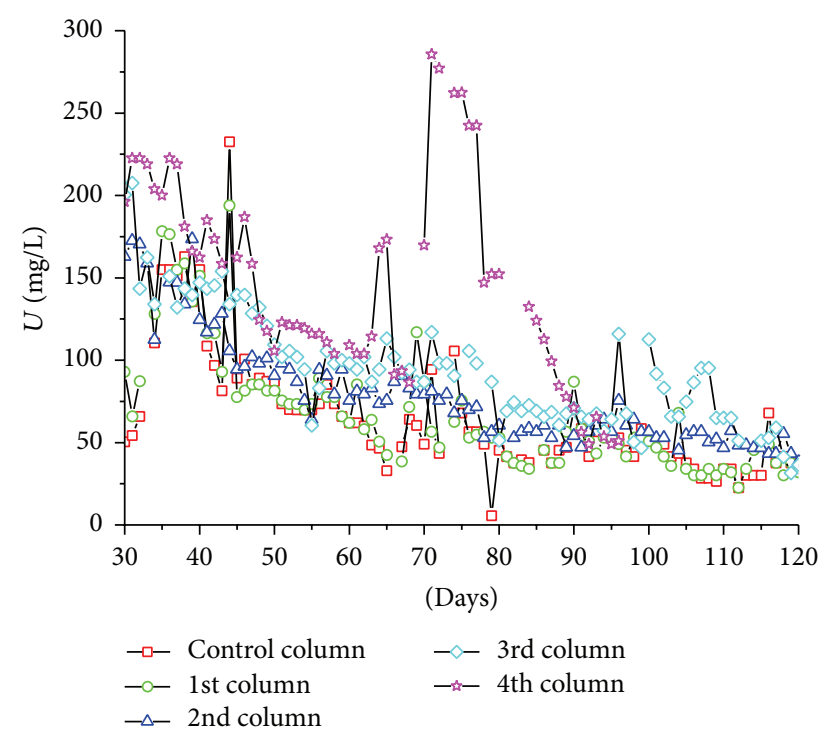

(b)

FIGURE 6: Uranium concentration of PLS for each column during the leaching. (a) From 1 to 30 days and (b) from 31 to 120 days.

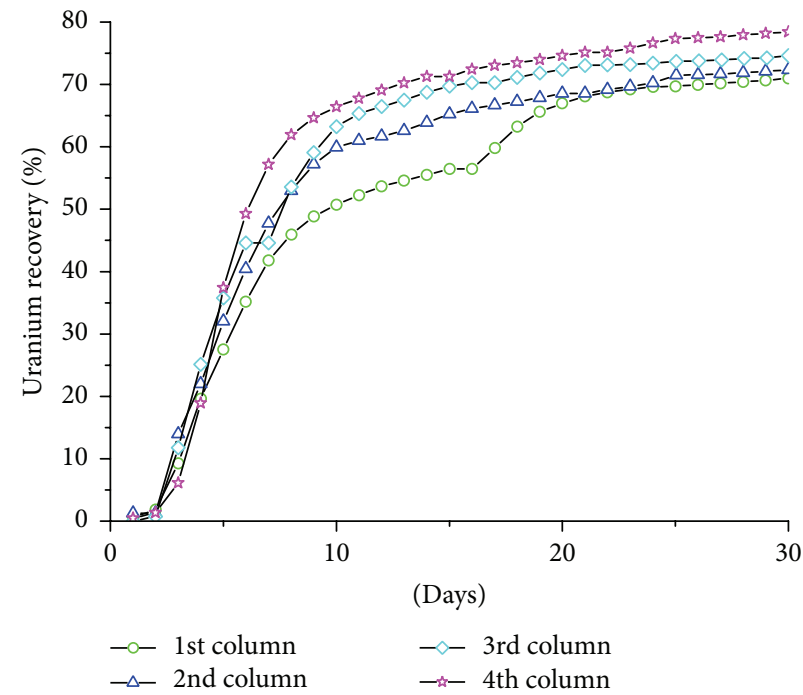

(a)

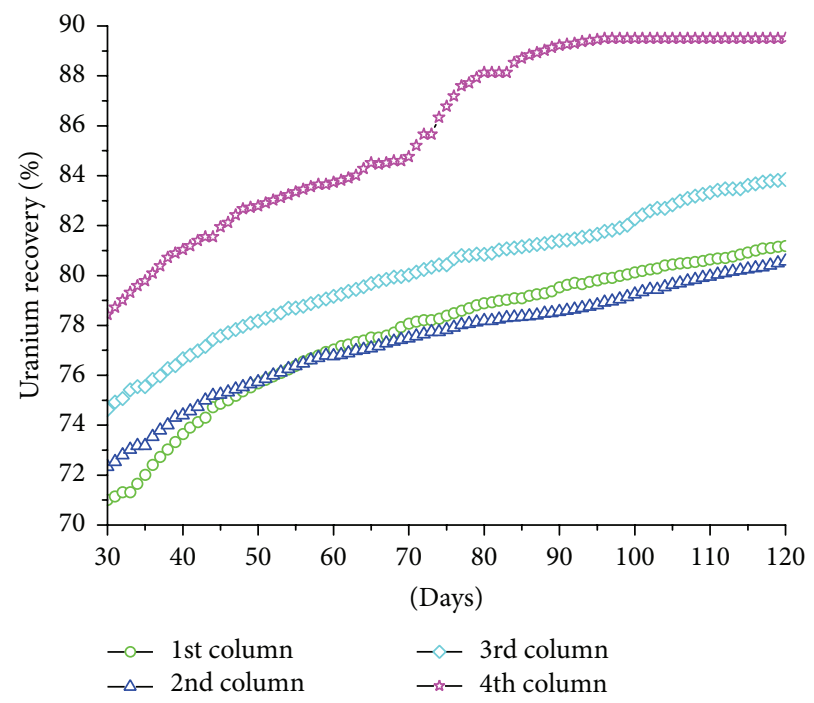

(b)

FIGURE 7: Uranium recovery for each column during the leaching. (a) In the first 30 days; (b) in the next 90 days.

uranium minerals are leaching because they can dissolve in acid normally. In this period, the redox potential and the concentration of uranium have no correlation relationship which are presented in Figure 6(a). There is a big peak for uranium concentration for each column in the fifth day. However, the peak of 4th column is the highest one and that of the 3rd column is the second. The peaks for the control column and the 1st column are much lower than the later columns. This is because the later column utilized the PLS of the former column which contains ferric iron as stronger oxidizing agent. The other reason is that the bacteria can adapt more easily to the leaching environment which contains high fluorine and other toxic ions after adopting extreme toxic iron environment in former column. That is, bacteria activity was enhanced after they underwent the former column.

Figure 6(a) shows the uranium concentration of PLS with different column in bioleaching stage. The $\mathrm{U}$ concentration of PLS from 4th column is higher than those of others. The average uranium concentration of PLS is $67 \mathrm{mg} / \mathrm{L}$ of $1 \mathrm{st}$ column, $80 \mathrm{mg} / \mathrm{L}$ of 2 nd column, $95 \mathrm{mg} / \mathrm{L}$ of $3 \mathrm{rd}$ column, and $147 \mathrm{mg} / \mathrm{L}$ of 4 th column. Obviously, the average uranium concentration of PLS of later column is higher than that of the former one. This system can increase the uranium concentration of PLS. This is good for the iron exchange system to recover the uranium. 
In acid leaching stage (in the first 30 days), about $65 \%$ to $70 \%$ totally were leached in the first 30 days as shown in Figure 7(a). The major uranium mineral is pitchblende which can be easily leached by acid with $\mathrm{O}_{2}$. Because the PLS contains bacteria and ferric iron from the former column as irrigation solution, in this stage, uranium can be leached more efficiently which has more ferric iron or bacteria. Thus, the recovery of 4 th is greater than that of 3 rd column, and that of 3 rd is greater than 2 nd column and so on.

After 120 days of bioleaching, the uranium recovery was $81.0 \%$ for the 1st column, $81.8 \%$ for the 2 nd column, $87.5 \%$ for the 3 rd column, and $89.5 \%$ for the 4 th column, respectively, as shown in Figure 7(b). The uranium recovery of the 4th column is over $8.5 \%$ more than that of the 1 st column. The result demonstrates that the highest leaching of base metals is achieved at low $\mathrm{pH}$ values under high redox conditions where ferric iron remains in solutions [16].

\section{Summary}

The continued multicolumns bioleaching is seen to be very effective for leaching uranium. After $120 \mathrm{~d}$ of continued multicolumns bioleaching, the acid consumption of the last column was $33.6 \mathrm{~g} / \mathrm{kg}$, which is much less than that of acid leaching. The uranium recovery is highly leached (89.5\%). The highest uranium concentration $(4000 \mathrm{mg} / \mathrm{L})$ is that from the 4th column. This technology can effectively enhance both bacteria activity and uranium concentration of PLS. It improved the iron exchange system to recover uranium. Furthermore, this continued multicolumns bioleaching system can reuse the acid of PLS and reduce the acid consumption. The cost can be reduced by this technology.

\section{Competing Interests}

The authors declare that they have no conflict of interests.

\section{Acknowledgments}

This work was financially supported by National 973 Plans (Grant no. 2015CB453000), Joint Fund Project of National Natural Science Foundation of China (U1501231), the Science and Technology Project of Jiangxi Province Education Department (no. GJJ12752), Science and Technology Project of Jiangxi Province (no. 20133BFB29004), the International Science and Technology Cooperation Project of China (no. 2011DFR60830), China Postdoctoral Science Foundation of Jiangxi Province (JX2014KY48), and Project of Key Laboratory of Radioactive Geology and Exploration Technology Fundamental Science for National Defense (Z1508).

\section{References}

[1] A. Potysz, P. N. L. Lens, J. van de Vossenberg et al., "Comparison of $\mathrm{Cu}, \mathrm{Zn}$ and $\mathrm{Fe}$ bioleaching from $\mathrm{Cu}$-metallurgical slags in the presence of Pseudomonas fluorescens and Acidithiobacillus thiooxidans," Applied Geochemistry, vol. 68, pp. 39-52, 2016.
[2] S. Ilyas, J.-C. Lee, and R.-A. Chi, "Bioleaching of metals from electronic scrap and its potential for commercial exploitation," Hydrometallurgy, vol. 131-132, pp. 138-143, 2013.

[3] G. Zou, S. Papirio, X. Lai et al., "Column leaching of low-grade sulfide ore from Zijinshan copper mine," International Journal of Mineral Processing, vol. 139, article 2730, pp. 11-16, 2015.

[4] M. L. Rodrigues, K. C. Lopes, H. C. Leôncio, L. A. Silva, and V. A. Leão, "Bioleaching of fluoride-bearing secondary copper sulphides: column experiments with Acidithiobacillus ferrooxidans," Chemical Engineering Journal, vol. 284, pp. 12791286, 2016.

[5] J. A. Muñoz, M. L. Blázquez, A. Ballester, and F. González, “A study of the bioleaching of a Spanish uranium ore. Part III: column experiments," Hydrometallurgy, vol. 38, no. 1, pp. 7997, 1995.

[6] Z.-J. Peng, R.-L. Yu, G.-Z. Qiu et al., "Really active form of fluorine toxicity affecting Acidithiobacillus ferrooxidans activity in bioleaching uranium," Transactions of Nonferrous Metals Society of China, vol. 23, no. 3, pp. 812-817, 2013.

[7] Y. Yang, W. Liu, S. K. Bhargava, W. Zeng, and M. Chen, "A XANES and XRD study of chalcopyrite bioleaching with pyrite," Minerals Engineering, vol. 89, pp. 157-162, 2016.

[8] J. Park, Y. Han, E. Lee et al., "Bioleaching of highly concentrated arsenic mine tailings by Acidithiobacillus ferrooxidans," Separation and Purification Technology, vol. 133, pp. 291-296, 2014.

[9] Abhilash, B. D. Pandey, and A. K. Singh, "Comparative performance of uranium bioleaching from low grade indian apatite rock in column and bioreactor," Energy Procedia, vol. 39, pp. 2032, 2013.

[10] M. Shahrabi-Farahani, S. Yaghmaei, S. M. Mousavi, and F. Amiri, "Bioleaching of heavy metals from a petroleum spent catalyst using Acidithiobacillus thiooxidans in a slurry bubble column bioreactor," Separation and Purification Technology, vol. 132, pp. 41-49, 2014.

[11] L. Castro, M. L. Blázquez, F. González, J. A. Muñoz, and A. Ballester, "Reductive leaching of jarosites by Aeromonas hydrophila," Minerals Engineering, vol. 95, pp. 21-28, 2016.

[12] L. Gunneriusson, Å. Sandström, A. Holmgren, E. Kuzmann, K. Kovacs, and A. Vértes, "Jarosite inclusion of fluoride and its potential significance to bioleaching of sulphide minerals," Hydrometallurgy, vol. 96, no. 1-2, pp. 108-116, 2009.

[13] V. Fonti, A. Dell'Anno, and F. Beolchini, "Does bioleaching represent a biotechnological strategy for remediation of contaminated sediments?" Science of the Total Environment, vol. 563-564, pp. 302-319, 2016.

[14] J. A. Muñoz, F. González, M. L. Blázquez, and A. Ballester, "A study of the bioleaching of a Spanish uranium ore. Part I: a review of the bacterial leaching in the treatment of uranium ores," Hydrometallurgy, vol. 38, no. 1, pp. 39-57, 1995.

[15] J.-U. Lee, S.-M. Kim, K.-W. Kim, and I. S. Kim, "Microbial removal of uranium in uranium-bearing black shale," Chemosphere, vol. 59, no. 1, pp. 147-154, 2005.

[16] A. Cecal, K. Popa, M. Craus, S. Patachia, and R. T. Moraru, "Bioleaching of $\mathrm{UO}_{2}^{2+}$ ions from a Romanian poor uranium ore," Journal of Radioanalytical and Nuclear Chemistry, vol. 254, no. 1, pp. 81-84, 2002. 

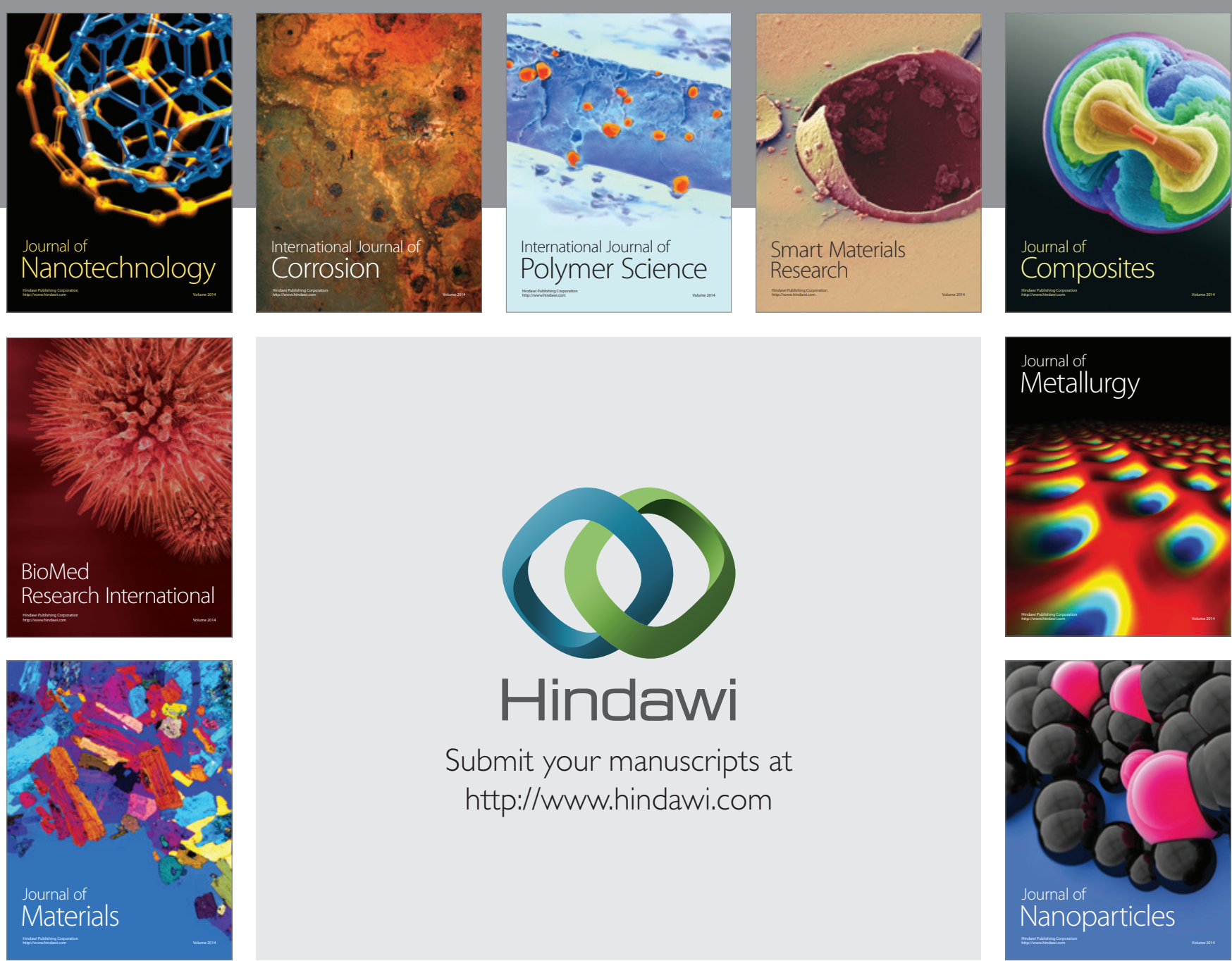

\section{Hindawi}

Submit your manuscripts at

http://www.hindawi.com

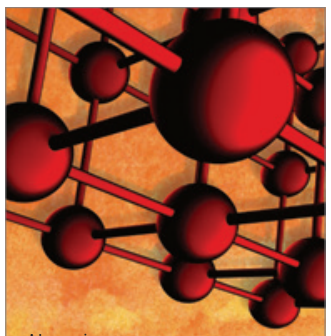

Materials Science and Engineering
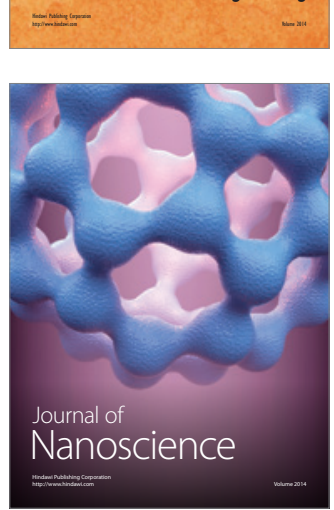
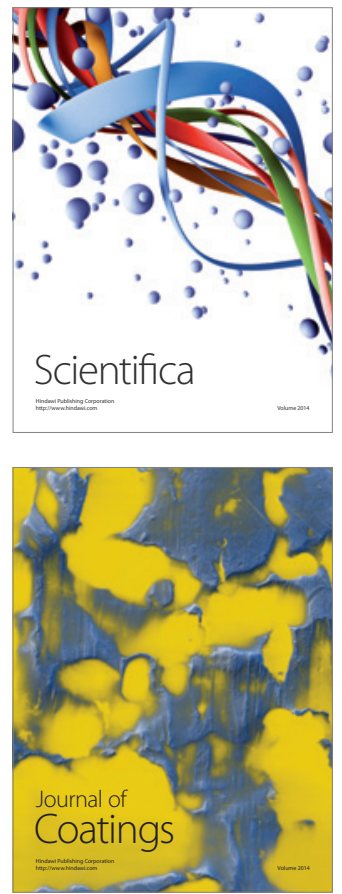
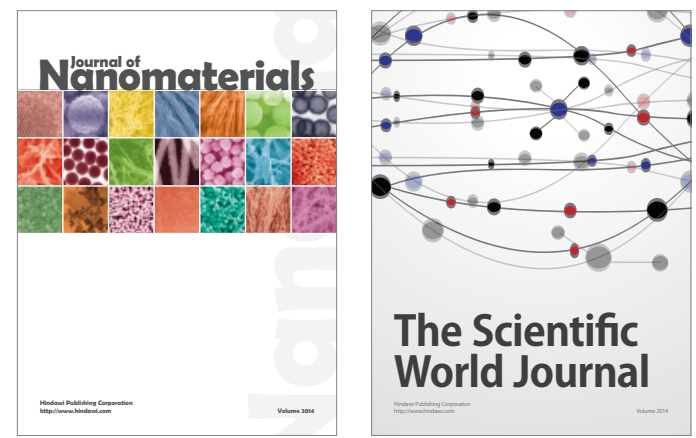

The Scientific World Journal
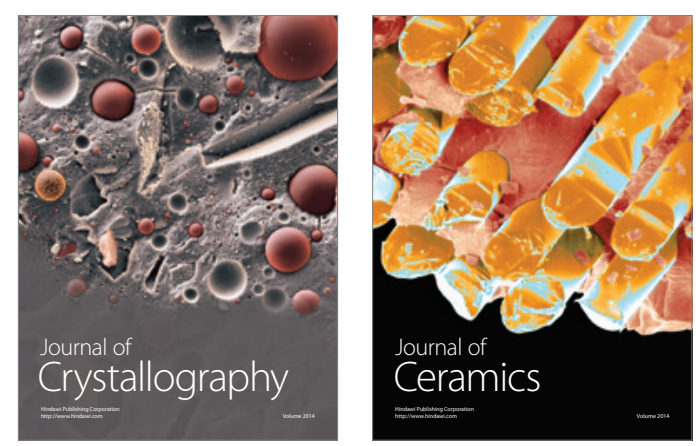
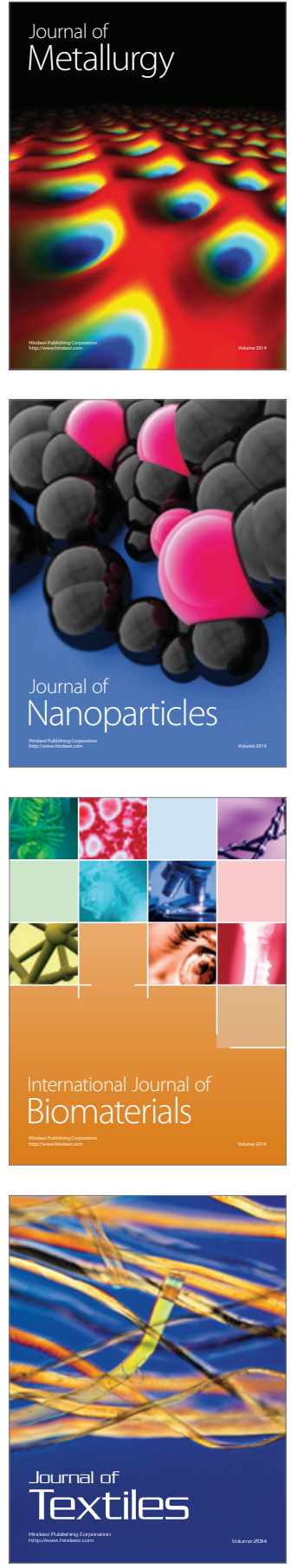